\title{
NON-GENETIC FACTORS AFFECTING THE INCIDENCE OF CALVING ABNORMALITIES IN CROSSBRED COWS
}

KEY WORDS:

Nitin

Wakchaure*

\section{Ravinder} Malhotra

\section{Udita Chaudhary}

\section{Dilip Deokar}

Assistant Professor, Department of Dairy Economics and Business Management, Guru Angad Dev Veterinary and Animal Sciences University, Ludhiana, Punjab, India. *Corresponding Author

Principal Scientist, Division of Dairy Economics Statistics and Management, ICAR-National Dairy Research Institute, Karnal, Haryana, India.

Scientist (SS), Division of Dairy Economics Statistics and Management, ICARNational Dairy Research Institute, Karnal, Haryana, India.

Associate Professor, Department of Dairy Science and Animal Science, Mahatma Phule KrishiVidyapeeth, Rahuri, Maharashtra, India.

Background: Calving abnormalities incudes reproductive disorders such as abortion and dystocia which affects the herd life and reproductive efficiency of dairy animals and ultimately the economics of dairy herds because of replacement from herd. Generally, crossbreds cows are more susceptible for the incidence of calving abnormalities as compared to the indigenous breeds.

Methods: For the present study, secondary data of calving abnormalities such as abortion and dystocia was collected from the disease records of Phule Triveni crossbred cows. The data consists of 2168 number of calvings records of abortion and dystocia during the period of 20 years from 1995-2014. The incidence of calving abnormalities such as abortion and dystocia were calculated as percentage for each period, season, parity, stage of lactation and level of production.

Results: The incidence of calving abnormalities was 8.53 per cent while the incidence of abortion and dystocia was 5.81 and 2.3 per cent. The incidence of abortion was higher during summer season (7.61 per cent) while that of dystocia in rainy season (3.00 per cent). The highest incidence of abortion was observed in fourth parity in case of abortion (10.86 per cent) and dystocia (3.37 per cent).

Conclusion: Non-genetic factors such as season, party, late stage of lactation and very high milk producing cows are predisposing factors for more occurrence of calving abnormalities in Phule Triveni crossbred cows, so more emphasis should be given to managemental practices to minimise the occurrence of incidence at farm level.

\section{INTRODUCTION}

The livestock sector in India plays a significant role as an alternative source of food and income. It is also important in the socio-economic development of the country in rural areas by means of generating employment, particularly among the landless, small and marginal farmers. Livestock sector also supplement additional income along with crop production and other sources to absorb income shocks due to crop failure in varying and fluctuating climatic conditions. The economic viability of a dairy enterprise depends primarily on milk production and reproduction efficiency of the herd. Out of four pillars of animal husbandry, i.e., breeding, feeding, management and disease control, disease control is the important and most critical factor to make livestock sector economically viable. Incidence of disease has a tremendous and adverse impact on the dairy industry due to morbidity, mortality, discarded milk, reduced milk production, huge treatment costs and replacement rate of dairy animals.

Reproductive disorders in livestock can only be minimized when sufficient information regarding reproductive status of the animals is available. The information on the incidence of various reproductive disorders in dairy crossbred cattle of advanced countries is well documented, but such estimates and studies are scanty in in India. Therefore, present study was conducted regarding the incidence of occurrence of calving abnormalities such as abortion and dystocia in crossbred cattle that helped to minimize the losses and economic burden of dairy farmers.

\section{MATERIALS AND METHODS:}

For the present study, secondary data of calving abnormalities such as abortion and dystocia was collected from the disease records of Phule Triveni crossbred cows. The data consists of 2168 number of calvings records of abortion and dystocia during the period of 20 years from 1995-2014.

\section{Incidence of reproductive disorders:}

Incidence is the number of new cases of the disease within a specified period of time (Woodward, 1999).

Incidence rate of disease $=\frac{\begin{array}{c}\text { Number of new cases of } \\ \text { disease in the lactation }\end{array}}{\begin{array}{c}\text { Number of animals in the } \\ \text { lactation }\end{array}} \times 100$

The incidence of calving abnormalities such as abortion and dystocia were calculated as percentage for each period, season, parity, stage of lactation and level of production. It was calculated by taking the proportion of animals affected from indicator traits in the lactation or calving.

\section{RESULTS AND DISCUSSIONS:}

The incidence of reproductive disorder i.e., calving abnormalities such as abortion and dystocia in relation to non-genetic factors such as period, season, parity, stage of lactation and level of production is described below.

\section{Incidence of calving abnormalities in Phule Triveni crossbred cows}

The number of cases of calving abnormalities observed was 185 out of total 2168 number of calvings. The finding of the present study revealed that incidence of calving abnormalities was 8.53 per cent. The findings of the present study was in agreement with Singh (1979), who also noted similar incidence in zebu crossbreds with Brown Swiss and lesser incidence in Zebu cattle, whereas Kumar and Reddy (1986) found higher incidence in Karan Fries cattle. Tomar and Verma (1988) reported lesser percentage of calving abnormalities in Karan Fries cattle.

Incidence of Abortion: 
In the present study, the incidence of abortion observed was 5.81 per cent. The findings of present study were in agreement with that of Lalrintluanga (2003) who reported incidence of 6.25 per cent in dairy cows, whereas contrary to the results of the present study, Vaccaro and Vaccaro (1981); Kulkarni (2002); Satyapal (2003) noted higher incidence of abortion in Brown Swiss cow, indigenous Gir along with their crossed cows and Karan Fries cows, respectively.

In comparison to the findings of the present study, Prabhu and Chatterjee (1970) observed 50 per cent more incidence of abortion (11-12 per cent) in crossbred cows than in zebu. Lesser incidence rate was observed by Roy and Tripathi (1989), Mukherjee et al. (1993), Urade (2001) and Chourewar et al. (2002) in Holstein-Friesian x Sahiwal-Tharparkar crosses, Karan Fries, Sahiwal with crossbred cows and in crossbred cows, respectively; while Islam and Nadroo (2006) assessed variation in the incidence rate of abortion in cattle from 1.96 to 8.33 per cent in crossbred cows and 4.55 to 7.70 per cent in Jersey.

The month-wise and year-wise incidence due to abortion is shown in Fig. 1 and Fig. 2 respectively.

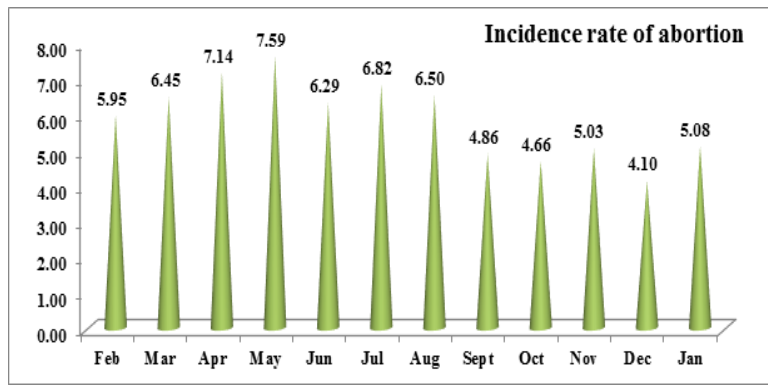

Fig. 1: Month-wise incidence rate of abortion in Phule Triveni crossbred cows

The month-wise incidence rate of abortion showed that the incidence rate was in the range of (4.10 to 7.59 per cent). Highest incidence rate was observed in the month of May, i.e., 7.59 per cent followed by in April, i.e., 7.14 per cent while lowest incidence rate was observed in the month of December (4.10 per cent) and 4.66 per cent in the month of October.

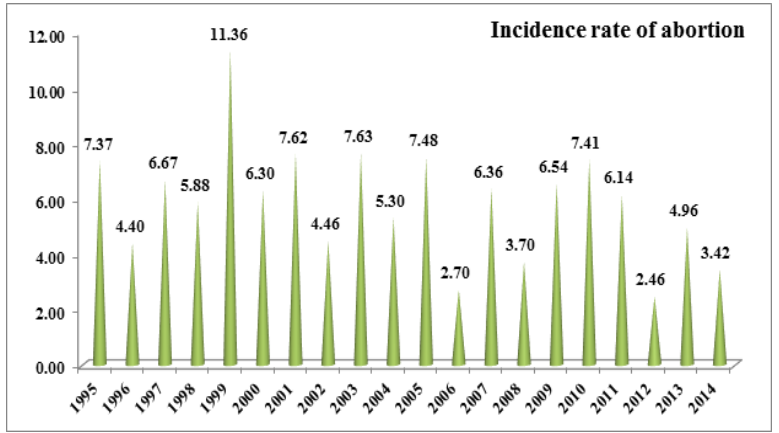

Fig. 2: Year-wise incidence rate of abortion in Phule Triveni crossbred cows

The year-wise incidence rate of abortion showed that highest incidence rate of 11.36 per cent was observed in the year 1999, while lowest incidence rate of 2.46 per cent was observed in the year of 2012 .

\section{Incidence of Dystocia:}

The results of the present study indicated that the incidence of dystocia was 2.3 per cent in crossbred cows. The outcomes of the present study coincide with the results of Pandit et al. (1982), Bhatnagar and Sharma (1985) and Mukherjee et al. (1993). Higher estimates of incidence of dystocia were reported in crossbred cows by Urade (2001), Kulkarni et al. (2002) and Satyapal (2003), while lower incidence of dystocia in crossbreds was reported by Saloniemi et al. (1986), Roy and Tripathi (1989) and Chourewar et al. (2002).

The month-wise and year-wise incidence due to abortion was shown in Fig. 3 and Fig. 4 respectively.

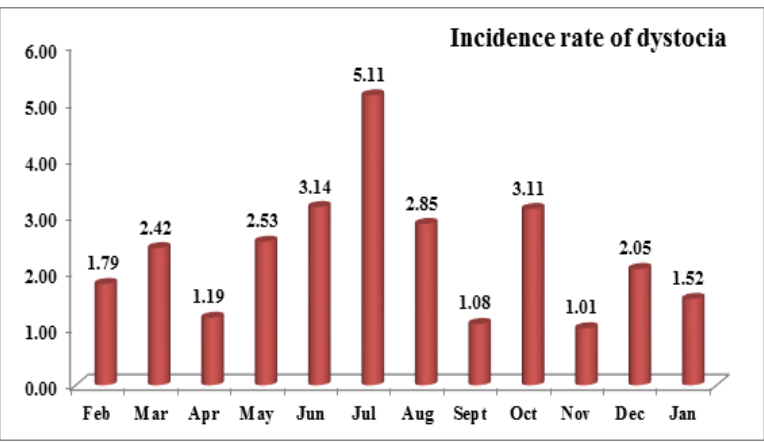

Fig. 3: Month-wise incidence rate of dystocia in Phule Triveni crossbred cows

The incidence of dystocia was in the range of 1.01- 5.11 per cent. Moreover, the highest occurrence of dystocia, i.e. 5.11 per cent was observed in the month of July, while in rest of the months it was below 3.14 per cent.

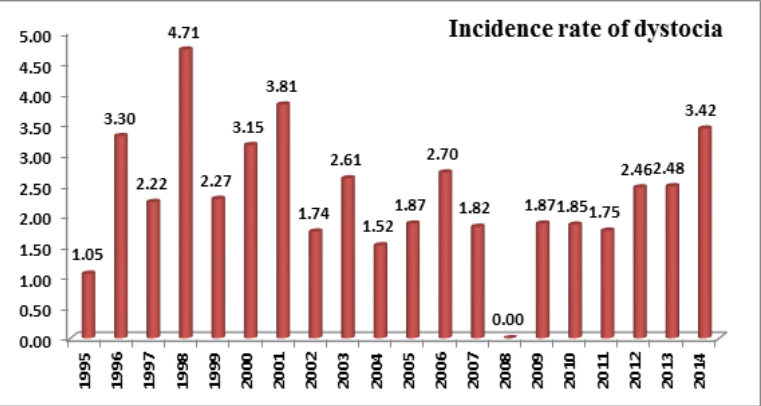

Fig. 4: Year-wise incidence rate of dystocia in Phule Triveni crossbred cows

The year-wise incidence of dystocia showed that in the month of December there was highest incidence of 4.71 per cent, 3.81 per cent in the year 2001 while lowest incidence of 1.05 per cent was noticed in the year 1995. In the year 2008, no case of dystocia was observed.

Incidence of calving abnormalities due to non-genetic factors in Phule Triveni crossbred cows:

The incidence of calving abnormalities which include abortion and dystocia due to non-genetic factors such as period, season, parity, stage of lactation and level of production were measured in terms of percentage. The incidence of calving abnormalities such as abortion and dystocia in relation to various non-genetic factors is discussed briefly here.

Incidence of abortion in relation to non-genetic factors: The results of present study showed that the incidence of abortion was higher during summer season (7.61 per cent) followed by more or less similar during winter and rainy (5.36 per cent and 5.74 per cent, respectively). The results of the present study are in agreement with the study of Mukherjee et al. (1993) that the incidence of abortion was low during winter but high during summer season due to stress level in hot climatic conditions in summer season. However, Pandey and Desai (1972) observed higher abortions during monsoon season which may be due to growth of organisms responsible for causing abortion in rainy climatic environmental conditions. 
Table 1: Incidence of abortion and dystocia in Phule Triveni crossbred cattle in association with non-genetic factors

\begin{tabular}{|c|c|c|c|c|c|c|}
\hline Non-genetic factors & Levels & No. of calvings & $\begin{array}{c}\text { No. of abortion } \\
\text { cases }\end{array}$ & $\begin{array}{c}\text { No. of dystocia } \\
\text { cases }\end{array}$ & $\begin{array}{c}\text { Incidence of } \\
\text { abortion }\end{array}$ & $\begin{array}{c}\text { Incidence of } \\
\text { dystocia }\end{array}$ \\
\hline \multirow[t]{4}{*}{ Period } & $1995-99$ & 449 & 32 & 12 & $7.13^{\mathrm{a}}$ & 2.67 \\
\hline & $2000-04$ & 594 & 37 & 15 & $6.23^{b}$ & 2.53 \\
\hline & $2005-09$ & 543 & 29 & 9 & $5.34^{\mathrm{c}}$ & 1.66 \\
\hline & $2010-14$ & 582 & 28 & 14 & $4.81^{d}$ & 2.41 \\
\hline \multirow[t]{3}{*}{ Season } & Winter & 784 & 37 & 15 & $5.36^{\mathrm{a}}$ & 1.91 \\
\hline & Summer & 618 & 42 & 12 & $7.61^{\mathrm{b}}$ & 1.94 \\
\hline & Rainy & 766 & 47 & 23 & $5.74^{\mathrm{a}}$ & 3.00 \\
\hline \multirow[t]{5}{*}{ Parity } & 1 & 539 & 44 & 14 & 3.15 & 2.60 \\
\hline & 2 & 489 & 23 & 10 & 3.48 & 2.04 \\
\hline & 3 & 337 & 17 & 9 & 7.42 & 2.67 \\
\hline & 4 & 267 & 17 & 9 & 10.86 & 3.37 \\
\hline & $5 \&$ above & 536 & 25 & 8 & 7.65 & 1.49 \\
\hline \multirow[t]{3}{*}{ Stage of lactation } & Early & 642 & 29 & 10 & 1.09 & 1.56 \\
\hline & Mid & 730 & 41 & 17 & 2.47 & 2.33 \\
\hline & Late & 796 & 56 & 23 & 5.40 & 2.89 \\
\hline \multirow[t]{4}{*}{ Level of production } & Very low & 689 & 7 & 7 & 1.02 & 1.02 \\
\hline & Low & 546 & 18 & 9 & 3.30 & 1.65 \\
\hline & High & 464 & 43 & 13 & 9.27 & 2.80 \\
\hline & Very high & 469 & 58 & 21 & 12.37 & 4.48 \\
\hline
\end{tabular}

Means with different superscript differ significantly $(\mathrm{P} \leq 0.01)$

The present study revealed that fourth period had lowest incidence of abortion in crossbred cows (4.81 per cent). However, there was no specific trend in the incidence of abortion across the different periods of calving. Contrary to the findings of the present study, Sharma (2010) revealed that third period had the highest incidence of abortion in both Karan Fries heifers (5.33 per cent) and all calvers (8.79 per cent).

The study noted that incidence of abortion varied from 3.15 to 10.86 per cent among the different parities. The highest incidence of abortion was observed lesser in first and second parity (3.15 and 3.48 per cent) and higher in the remaining parities, as it was more or less similar from 7.42 to 10.86 per cent. The result of the present study is in agreement to study done by Markus feld Nir (1997) who reported higher pregnancy losses in multiparous cows.

In agreement with the findings of present study, the study conducted by Kaikini et al. (1983) revealed that the overall incidence of reproductive disorders was highest in $5^{\text {th }}$ lactation and Sharma (2010) noted lowest incidence of abortion in first parity (3.32 per cent) in Karan fries cows. The higher risk of abortion at increased age in cows is similar to humans (Skjærven and Klungsøyr, 2007). The probable reason for higher incidence of abortion in primiparous cows could be that primiparous cow remains in negative energy balance (Ghorbani and Asadi-Alamoti, 2004). The cow lose body weight which caused reduction in body condition score corresponding with negative correlation with progesterone hormone secretion \& would be detrimental for fetal survival (Spicer et al.1990; Grimard et al, 2006).

Incidence of dystocia in relation to non-genetic factors: The study showed that period-wise incidence of dystocia varied from 1.66 to 2.67 in Phule Triveni crossbred cows. The higher period wise incidence was noted by Sharma (2010) which varied within range of 5.88 to 9.17 per cent.

The incidence of dystocia in rainy season was noted 3.00 per cent followed by more or less similar incidence during winter (1.91 per cent) and summer (1.94 per cent). Andersen and Plum (1965) reported that calves born during winter season had slightly longer gestations and little heavier at birth as compared to in summer and rainy season. Johanson and www.worldwidejournals.com |
Berger (2003) observed that calves born in winter need more assistance than calves born in summer.

The results obtained from the present study showed that the incidence was higher in fourth parity (3.37 per cent) but lowest during fifth and above parities (1.49 per cent) in crossbred cows. On the other hand, Satyapal (2003), Sharma (2010) and Uzmay et al. (2010) and Gaafar et al. (2011) noted that the incidence of dystocia was higher in first parity in crossbred cows, and the frequency of dystocia occurrence decreases with the increase in the age and parity of the cows because the chances of occurrence of dystocia in heifer was more as compared to in cows due to their body condition score.

\section{CONCLUSION:}

The highest incidence rate of $7.13,7.61,10.86,5.40$ and 12.37 per cent was observed during 1995-99, summer season, $4^{\text {th }}$ parity, late stage of lactation and in very high milk producing cows, respectively in abortion while in case of dystocia, the highest incidence of $2.67,3.00,3.37,2.89$ and 4.48 per cent reveled was seen during $1995-99$ period, rainy season, $4^{\text {th }}$ parity, late stage of lactation and in very high milk producing cows, respectively. It was concluded that the non-genetic factors such as period, parity, stage of lactation and level of production were caused highest incidence in cases of both abortion and dystocia calving abnormalities in Phule Triveni crossbred cows.

\section{Acknowledgement:}

The authors of the present study express their regards and gratitude to Research-cum-Development Project (RCDP), Rahuri dairy farm for their kind support and help during the data collection.

\section{REFERENCES}

1. Andersen, H., and Plum, M. (1965). "Gestation length and birth weight in cattle and buffaloes: a review."Journal of Dairy Science, 48, 1224-1235.

2. Bhatnagar, D.S., and Sharma, R.C. (1985). "Reproductive status of Karan Swiss heifers." Agriculture Science Digest, 5(1), 57-59.

3. Chourewar, S., Ali, S.Z., and Kuralkar, S.V. (2002). "Incidence of reproductive disorders in crossbred cows." Indian Journal of Dairy Science, 55(5), 313-315.

4. Gaafar, H.M., Shamiah, S.M., El-Hamd, M.A., Shitta, A.A., and El-Din, M.A. (2011). "Dystocia in Friesian cows and its effects on postpartum reproductive performance and milk production."'Tropical Animal Health Production, 43(1), 229-234.

5. Ghorbani, G., and Asadi-Alamoti, A. (2004). "Developed management of dairy cattle." 'lst ed. Industrial Unit of Jahad, Isfahan, Iran. Pp.92-100.

6. Grimard, B., Freret, S., Chevallier, A., Pinto, A., Ponsart, C., and Humblot, P. (2006). Genetic and environmental factors influencing first service conception rate and late embryonic/foetal mortality in low fertility dairy 


\section{herds. Animal Reproduction Science, $91(1-2), 31-44$}

7. Islam, R., and Nadroo, G.A. (2006). "Incidence of abortion and still birth in cattle in an organized farm of Kashmir valley." Indian Veterinary Journal, 83(10), 1127-1128.

8. Johanson, J., and Berger, P.J. (2003). Birth weight as a predictor of calving ease and perinatal mortality in Holstein cattle." Journal of Dairy Science, 86(11), 3745-55.

9. Kulkarni, M.D., Khanvikar, A.V., and Bansod, R.S. (2002). Incidence of reproductive disorders in indigenous and crossbred in an organized farm." Indian Veterinary Journal, 79, 1196-1197.

10. Kumar, S., and Reddy, K.M. (1986). "Studies on calving problems in primiparous crossbred cattle." M.Sc. thesis. Kurukshetra University, Kurukshetra.

11. Lalrintluanga, K. (2003). "Incidence of abortion in crossbred dairy cows in Mizoram."'Indian Veterinary Journal, 80(1), 74-75.

12. Markusfeld-Nir, O. (1997). "Epidemiology of bovine abortions in Israeli dairy herds."Preventive Veterinary Medicine,31,245-255.

13. Mukherjee, K.,Tomar, S.S., and Sadana,D.K. (1993). "Genetic studies on udder problems in Karan Fries herd."'Indian Vet.J., 70(2), 121-124.

14. Pandey, H.S. and Desai, R.N. (1972). "Incidence of abortion in crossbred cows in heavy rainfall areas." Indian Veterinary Journal, 63,52 1-524.

15. Pandit, R.K., Shukla, S.P. and Parekh, H.K.B. (1981). Incidence of retained placenta in Gir and their crosses with a special reference to subsequent fertility." Indian Journal Animal Science, 51 (5), 505-507.

16. Prabhu, S.S., and Chatterjee, S.N. (1970). "Incidence of abortion in Indian cattle.' Indian Journal Animal Science, 40,266.

17. Roy, P.K., and Tripathi, V.N. (1989). Incidence of different types of calving and its effect on various economic traits of crossbred cattle. Indian Journal of Dairy Science, $42(3), 440448$.

18. Saloniemi, H., Grohn,Y., and Syvejervi,J. (1986). Anim. Breed Abstr., 55, 2020.

19. Satyapal. (2003). "Investigation on health disorders in dairy cattle and buffaloes during pre and post-partum period." Ph.D Thesis submitted to NDRI, Karnal.

20. Sharma, P.C. (2010). "Genetic evaluation of Karan Fries cows for functional traits." Ph. D. Thesis, NDRI, (Deemed University), Karnal, India.

21. Singh, R.N. (1979). "Influence of breed groups (Zebu X Exotic) on health, production and breeding efficiency." Ph.D.Thesis submitted to NDRI, Karnal.

22. Skjærven, R. and Klungsøyr, K. (2007). "Selective fertility the examples of perinatal death and pre-eclampsia." Norwegian Epidemiology, 17(2), $175-180$.

23. Spicer, L.J., Tucker,W.B., and Adams, G.D. (1990). "Insulin-like growth factor-I in dairy cows: relationships among energy balance, body condition score, ovarian activity, and estrous behaviour." Journal of Dairy Science, 73: 929-937.

24. Tomar, S.S., and Verma, G.S. (1988). "Genetic variability in the components of replacement in Karan Fries cattle." Indian Journal of Animal Sciences, 58(10), 1204-1208.

25. Urade, G.K. (2001). "Incidence of reproductive disorders in pure Sahiwal and crossbred cows in Vidharbha region of Maharashtra." Indian Veterinary Journal, 78,741-742.

26. Uzmay, C., Kaya, I., and Ayyilmaz, T. (2010). "Analysis of risk factors for dystocia in a Turkish Holstein herd." Journal of Animal and Veterinary Advances, 9(20), 2571-2577.

27. Vaccaro, R. and Vaccaro, L.D. (1981). "Age at first calving and reproductive traits in daughters of Brown Swiss and Friesian bulls." Animal Breeding Abstract, 52,6555.

28. Woodward, M. (1999). "Epidemiology: Study Design and Data Analysis" Book published DOI:10.2307/1271123 Corpus ID: 62768884, Copyright 2001 John Wiley \& Sons, Ltd 